ISSN1027-5495. Functional Materials, 24, No.4 (2017), p. 699-706

\title{
Study of biofilms based on filamentous bamboo for surface water bioremediation
}

\author{
Zhang Huifang ${ }^{1,2}$, Cao Wenping ${ }^{2}$, Sun Ling $^{2}$, Liu Hanhu ${ }^{1}$ \\ ${ }^{1}$ School of Environmental Science and Spatial Informatics, China \\ University of Mining and Technology, Xuzhou, Jiangsu 221000, China \\ ${ }^{2}$ College of Environmental Engineering, Xuzhou Institute of Technology, \\ Xuzhou, Jiangsu 221000, China
}

\section{Received October 1,2017}

Two kinds of fillers were chosen to explore surface water remediation with a sequencing batch biofilm reactor (SBBR). By comparing SBBR with the plastic filling reactor (PFR), which was considered as the control group, the effectiveness of a filamentous bamboo reactor (FBR) for removing organic substances, nitrogen and phosphorous as well as biomass changes. Experimental results suggested that in using a FBR the average removal rates of $\mathrm{COD}_{\mathrm{Mn}}, \mathrm{TN}, \mathrm{NH}_{4}{ }^{+}-\mathrm{N}$ and $\mathrm{NO}_{3}{ }^{-} \mathrm{N}$ were $65.70 \%, 62.18 \%, 48.55 \%$ and $65.29 \%$ respectively when their initial concentration were $8.81-9.53 \mathrm{mg} \cdot \mathrm{L}^{-1}, 7.20-8.51 \mathrm{mg} \cdot \mathrm{L}^{-1}, 2.71-3.62 \mathrm{mg} \cdot \mathrm{L}^{-1}$ and 4.13 - 5.22 $\mathrm{mg} \mathrm{L}^{-1}$. In spite of remarkable advantages over PFR in removing $\mathrm{COD}_{\mathrm{Mn}}$, $\mathrm{TN}$, $\mathrm{NH}_{4}{ }^{+}-\mathrm{N}$ and $\mathrm{NO}_{3}-\mathrm{N}$, FBR was not quite effective for removing TP. The uses of bamboo filaments as carriers and carbon source, their high content of hydrophilic functional groups and abundant microbial facies were major reasons why FBR could remedy waters effectively. Keywords: Bamboo Filament, SBBR, Ex-situ Remediation, Surface Water, Eutrophication

\begin{abstract}
Рассмотрены два типа наполнителей для исследования рекультивации поверхностных вод с помощью последовательного биопленочного реактора (SBBR). При сравнении SBBR c реактором с пластиковым наполнителем (PFR), который рассматривался как контрольная группа, показана эффрективность нитевидного бамбукового реактора (FBR) для удаления органических веществ, азота и фосфора, а также биомассы. Экспериментальные результаты показали, что при использовании бамбукового наполнителя в биопленочном реакторе средняя скорость удаления $\mathrm{COD}_{\mathrm{Mn}}, \mathrm{TN}, \mathrm{NH}_{4}{ }^{+} \mathrm{N}$ and $\mathrm{NO}_{3}{ }^{-} \mathrm{N}$ выше, чем при использовании пластикового наполнителя. Несмотря на значительные преимущества перед PFR при удалении $\mathrm{COD}_{\mathrm{Mn}}, \mathrm{TN}, \mathrm{NH}_{4}{ }^{+}-\mathrm{N}$ and $\mathrm{NO}_{3}-\mathrm{N}, \mathrm{FBR}$ не был достаточно эффрективным для удаления ТР. Использование бамбуковых нитей в качестве носителей и источника углерода, их высокое содержание гидрофильных функциональных групп и обильная микробная фация способствовали эффрективному восстанавлению воды.
\end{abstract}

Вивчення біоплівки на основі ниткоподібного бамбука для біоремедіації поверхневих вод. Zhang Huifang, Cao Wenping, Sun Ling, Liu Hanhu.

Розглянуто два типи наповнювачів для дослідження рекультивації поверхневих вод за допомогою послідовного біоплівкового реактора (SBBR). При порівнянні SBBR з реактором 3 пластиковим наповнювачем (PFR), який розглядався як контрольна група, показана ефективність ниткоподібного бамбукового реактора (FBR) для видалення органічних речовин, азоту і фосфору, а також біомаси. Експериментальні результати показали, що при використанні бамбукового наповнювача в біоплівковому реакторі середня швидкість видалення $\mathrm{COD}_{\mathrm{Mn}}, \mathrm{TN}, \mathrm{NH}_{4}{ }^{+}-\mathrm{N}$ and $\mathrm{NO}_{3}-\mathrm{N}$ вище, ніж при використанні пластикового наповнювача. Показано, що FBR недостатньо ефективний для видалення ТР. Використання бамбукових ниток в якості носіїв і джерела вуглецю, їх високий вміст гідрофрільних фуннкціональних груп і рясна мікробна фрація сприяли ефективному відновленню води. 


\section{Introduction}

Eutrophication of surface waters results from human activities, fast urbanization, industrialization and intensive agricultural production [1]. It reduces biodiversity, recreational value of natural waters and ability of water self-purification. Ecological restoration includes in-situ and ex-situ remediation. In-situ remediation is a technique for effectively purifying polluted surface waters. In fact, many in-situ remediation techniques such as ecological floating beds and artificial wetlands have been widely used for remedying polluted surface waters and achieved satisfactory outcomes; the plant products processed may be further employed as food of animals and even human beings or processed into biogas, bio-fertilizer, and biomaterials $[2,3]$. However, these technologies have a range of unexpected deficiencies arising from low temperature, limited intake of plants, limited biomass concentration and low water transparency[4]. In particular, plants are often dead because their roots can't breathe or stop their growth at low temperature when some severely polluted surface waters are remedied by plants; after the remediation, pollutants in water are transferred by harvesting plants. In some areas where economy and management are underdeveloped, plants are not normally harvested and often discarded anywhere, so there are hidden dangers of secondary pollution [5].

In numerous experimental studies and projects, polluted surface waters have been restored by ex-situ remediation of biofilms, which has been found to be fairly effective for remediation [6,7]. Biofilm process can avoid all problems such as plant harvest, impossibility for plant roots to breathe owing to excessively high concentration of pollutants, subsequent management and poor effects at low temperature. It is a pretty mature technique that has been used for biological treatment of wastewater and can be managed in very simple way. To be sure, problems like slow formation of biofilms on the surface of biological carriers and low content of biomass also impact the surface water remediation by biofilm process. In addition, biofilm carriers directly impact processing efficiency and energy consumption of the biofilm process $[8,9]$, so it is especially important for ex-situ remediation of a biofilm process by selecting economical biological carriers suitable for water remediation. With the constant development of biofilm carriers, people have not only examined conventional characteristics of biofilm carriers such as specific surface area, roughness, porosity and manufacturing costs, but also proposed higher requirements for their biological affinity, hydrophilicity and oxygen transfer abilities. In previous studies, inert biological carriers like plastic fillers and light ceramic fillers have been extensively utilized for bioremediation of polluted waters, whereas degradable materials have been rarely reported to be used as biofilm carriers. For special eutrophicated water bodies that fall between domestic wastewater and ordinary surface waters, category and characteristics of selected carrier would impose significant impacts upon the results of ex-situ remediation, whereas no report has comparatively studied the selection of different biofilm carriers for eutrophicated water bodies.

The objectives of this study are as follows:

(1) Eutrophicated water bodies were treated by assembling FBR and PFR to determine the removal rate of $\mathrm{COD}_{\mathrm{Mn}}, \mathrm{NH}_{4}^{+}-\mathrm{N}, \mathrm{NO}_{3}^{-}-\mathrm{N}$, $\mathrm{NO}_{2}^{-}-\mathrm{N}, \mathrm{TN}$ and $\mathrm{TP}$, in order to evaluate effectiveness and properties of biofilm processes based on different fillers for remedying eutrophicated water bodies.

(2) Their mechanisms of action were analyzed from the microscopic perspective of eutrophicated water bodies, so as to provide references for selecting and optimizing biofilm carriers for ex-situ remediation of eutrophicated water bodies.

\section{Materials and methods}

\subsection{Experimental apparatus}

The water collected from the scenic lake of Xuzhou University of Technology was added to a reactor through a water inlet hose. The apparatus was mainly made from organic glass and looks like a cylinder with a total effective volume of $2.4 \mathrm{~L}$, an internal diameter of $9 \mathrm{~cm}$ and a height of $45 \mathrm{~cm}$. At the bottom, there was the sedimentation zone, where a blow-down pipe was laid. The water flew out of the pipe after it was treated. There was a zone of fillers in the middle of a reactor. The bamboo filaments and plastic fillers were added to corresponding reactors at an equal volume after they were treated. The blower (type: S-780) continuously aerated through an aeration plate at $0.05 \mathrm{~m}^{3} / \mathrm{h}$. Water was taken from the sampling connection on the upper part of the reactor.

\subsection{Experimental fillers}

In the experiment, plastic and bamboo filaments were used as fillers. Their characteristics are shown in Table 1.

The plastic fillers look like cylinders, made from polymethyl methacrylate by plastic injection moulding. They are full of void structures in the center with a bulk density of $0.66 \mathrm{Kg} / \mathrm{L}$. Bamboo filaments are made of bamboo in rectangles at a density of $1.1 \mathrm{Kg} / \mathrm{L}$. Before they are used, the bamboo filaments shall be consecutively soaked in $5 \%$ to $10 \%$ sodium hydroxide 
Zhang Huifang et al. / Study of biofilms based on filamentous ...

Table 1. Characteristics of Plastic Fillers and Bamboo Filaments

\begin{tabular}{|c|c|c|c|c|c|}
\hline Fillers & Materials & Size & Porosity $/ \%$ & $\begin{array}{c}\text { Specific Surface } \\
\text { Area } /\left(\mathrm{m}^{2} \cdot \mathrm{m}^{-3}\right)\end{array}$ & Fill Rate $\%$ \\
\hline $\begin{array}{c}\text { Bamboo } \\
\text { Filament }\end{array}$ & Bamboo & $10 \mathrm{~mm} \times 1 \mathrm{~mm} \times 1 \mathrm{~mm}$ & 85 & $158 \mathrm{~m}^{2} / \mathrm{m}^{3}$ & 40 \\
\hline Plastics & $\begin{array}{c}\text { XT Suspended } \\
\text { Fillers }\end{array}$ & $\varnothing 5 \mathrm{~mm} \times 7 \mathrm{~mm}$ & 48 & $160 \mathrm{~m}^{2} / \mathrm{m}^{3}$ & 40 \\
\hline
\end{tabular}

Table 2. Water quality indexes of water for experimental uses (mg/L)

\begin{tabular}{|c|c|c|c|c|c|c|}
\hline $\begin{array}{c}\text { Quality } \\
\text { parametres }\end{array}$ & $\mathrm{COD}_{\mathrm{Mn}}$ & $\mathrm{TN}$ & $\mathrm{NH}_{4}{ }^{+}-\mathrm{N}$ & $\mathrm{NO}_{2}{ }^{-}-\mathrm{N}$ & $\mathrm{NO}^{3-}-\mathrm{N}$ & $\mathrm{TP}$ \\
\hline Content & $8.81 \sim 9.53$ & $7.20 \sim 8.51$ & $2.71 \sim 3.62$ & $0.18 \sim 0.23$ & $4.13 \sim 5.22$ & $0.15 \sim 0.25$ \\
\hline
\end{tabular}

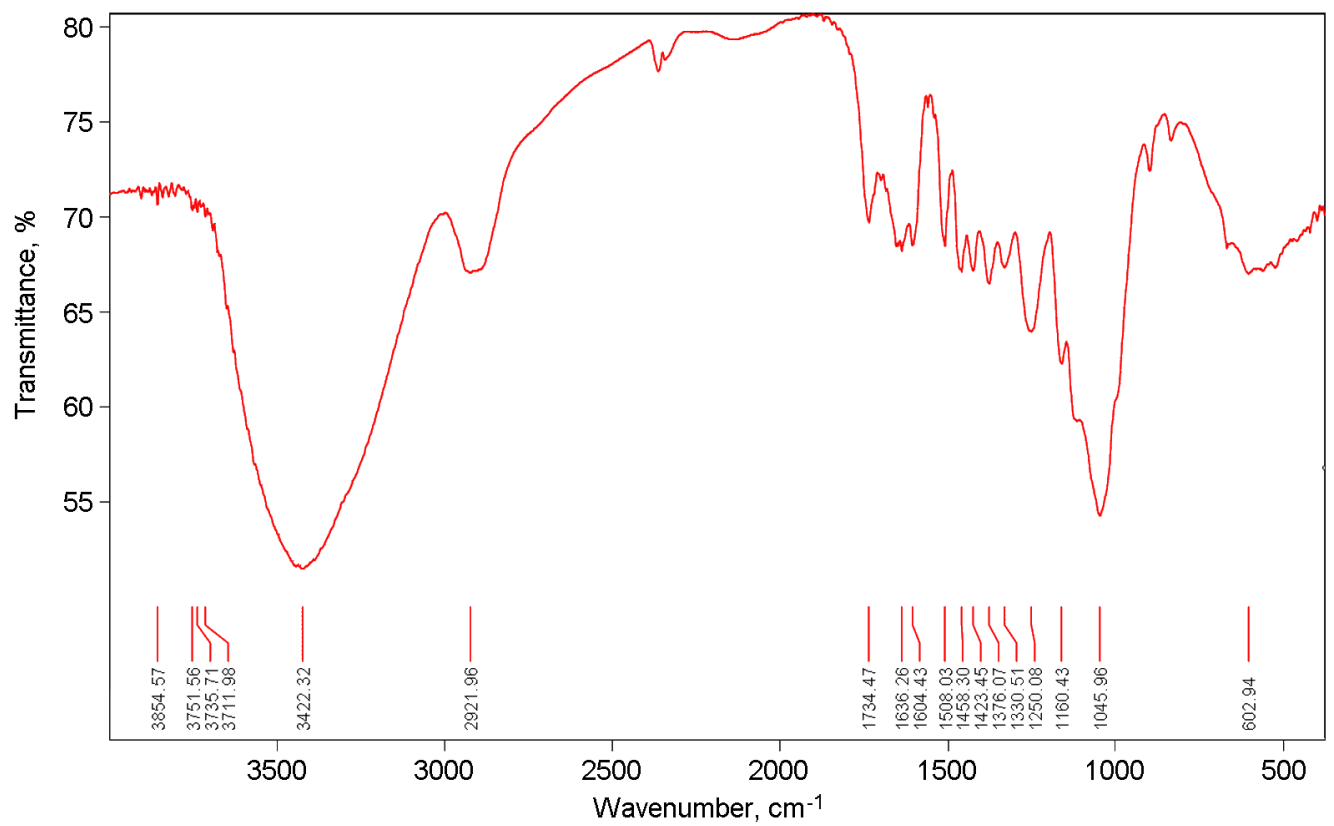

Fig.1. The infrared spectra of functional groups on the surface of bamboo filaments

solution for one week, in order that bamboo juice may be released out of the filaments as much as possible. The sampled filaments are cleaned, and dried by air. As shown in Fig 1, it may be observed from the infrared spectra that main functional groups include $-\mathrm{OH}$ $\left(3400 \mathrm{~cm}^{-1}, 1049 \mathrm{~cm}^{-1}\right.$, mainly in cellulose and polysaccharides $),-\mathrm{CH}_{2}\left(2920 \mathrm{~cm}^{-1}\right.$, mostly in fatty substances), and $-\mathrm{NH}_{2}\left(1650 \mathrm{~cm}^{-1}\right.$, mainly in proteins). These functional groups reveal that lots of microorganisms may adhere to the surface of bamboo filaments. They are easily enriched and proliferated on the surface of these filaments.

\subsection{Experimental methods}

The experiment lasted 16 days, including 12 days for biofilm formation on reactors and 4 days of the experimental period. Biofilms formed quickly on reactors by sludge discharge for inoculation. The returned sludge and sewage sampled from secondary settling tanks of Xuzhou Yaozhuang Sewage Treatment Plant were mixed at 1: 2 and then added to the reactors. The mixture was inoculated for $4 \mathrm{~h}$, aerated for $3 \mathrm{~h}$ and settled for $40 \mathrm{~min}$. It took $20 \mathrm{~min}$ to discharge water and sludge for $20 \mathrm{~min}$. There were three periods per day. After certain period of inoculation, the water at the outlet was tested. Compared with heterotrophic bacteria, nitrifying bacteria grew slowly and were sensitive to external conditions, so ammonia-nitrogen removal efficiency has been commonly reckoned as a symbol of biofilm maturity. The experiment was performed once biofilms formed after ammonia-nitrogen removal efficiency met designated requirements. In both reactors, the experiment was performed in the same way for SBBR. At the stage of water supply, the reactors didn't aerate, and dissolved 


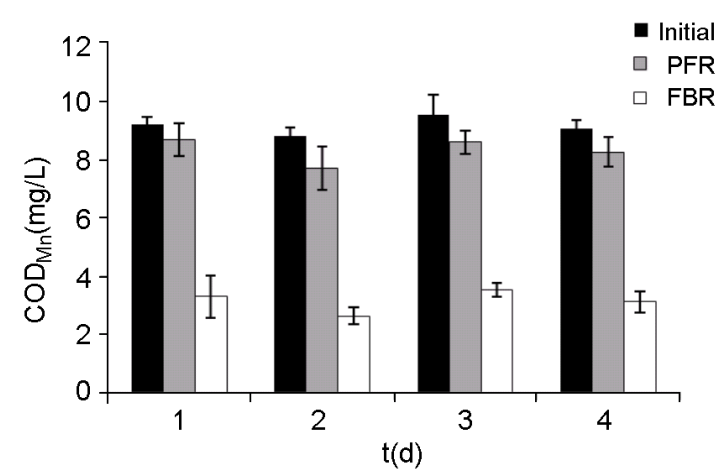

Fig. 2. Removal efficiency of $\mathrm{COD}_{\mathrm{Mn}}$

oxygen concentration was low. At the stage of aeration, organic substances and nitrogen were degraded. At the stage of sedimentation, there was neither water supply nor aeration, thus creating favorable sedimentation conditions for sludge. Sludge settleability was high and the concentration of suspension was low. The duration of each stage corresponds to the formation period of biofilms. In the experiment, water was collected from the Landscape Lake of Xuzhou Institute of Technology. The water temperature ranged within $20.0 \pm 0.5^{\circ} \mathrm{C}$ and the concentration of dissolved oxygen (DO) wasn't below $3.3 \mathrm{mg} \cdot \mathrm{L}^{-1}$. The six water quality indexes are shown in Table 2 .

\subsection{Analysis methods}

At the experimental stage, water was regularly sampled and measured within 2 hours. All water samples were filtered with $0.45 \mu \mathrm{m}$ microfiltration membranes. All compositions of water samples were analyzed within the experimental period. All measurements were based on national standards. The content of $\mathrm{NH}_{4}{ }^{+}-\mathrm{N}, \quad \mathrm{NO}_{2}{ }^{-}-\mathrm{N}$ and $\mathrm{NO}_{3}{ }^{-}-\mathrm{N}$ was measured with an ion-chromatography analyzer (Type: PIC-10A, purchased from Puren Instrument Co., Ltd, Qingdao, China); TN was measured by a UV-visible spectrophotometer (UV2450, supplied by Shimadzu, Japan), and COD Mn $_{\text {wn }}$ measured by acidic potassium permanganate titration. By photographing biotas, indicative protozoas, metazoas and bacteria on the surface of fillers were studied mainly by optical microscope (type: XSD-36XC), clean bench, electronic balance and water bath [10].

\section{Results and analysis}

\subsection{Comparison and analysis of $C O D_{M n}$ removal efficiency}

According to Fig 2, the average influent concentration of $\mathrm{COD}_{\mathrm{Mn}}$ was $8.81-9.53 \mathrm{mg} \cdot \mathrm{L}^{-1}$ in raw water; the average effluent concentration of PFR and FBR was 7.71-8.67 $\mathrm{mg} \cdot \mathrm{L}^{-1}$ and
2.63-3.53 $\mathrm{mg} \cdot \mathrm{L}^{-1}$ respectively. The average removal rate of CODMn was $9.29 \%$ and $65.7 \%$ respectively. Compared with $\mathrm{PFR}$, the FBR increased the average removal rate of CODMn by $56.41 \%$

Compared with plastic fillers, which are inert biological carriers, bamboo filaments, as natural biological carriers, are natural. On the surface of these filaments, there are many bar-shaped grooves, which contain lot of hydrophilic hydroxyls. Apart from rapid biofilm formation, stable biofilms can grow on the surface of the bamboo filaments. As a result, abundant microbial communities easily develop. They are not easily detached from the surface when the reactor is operated under aeration. Under this condition, a more complicated and longer food chain is created. In this chain, the bacteria and animalcules can prey on more organic and inorganic particles. The organic substances can be degraded more effectively. According to related data, evident interwoven structures exist in bacteria of bamboo filaments and are more adherent than all other carriers [11]. These interwoven structures can hunt macromolecular organic compounds that can be hardly degraded in water of reactors like a net. In addition, "induced enzyme" for degrading organic substances easily form inside the bamboo filament reactors because of high microbial activity, so refractory organic substances can be degraded. In the process of the experiment, it was discovered that the removal rate of $\mathrm{COD}_{\mathrm{Mn}}$ was low on the first day, which indicated that the reactor must adapt itself to the sewage during initial operations. As its operation carries on, the removal rate gradually increased. The removal rate fluctuated because water erosion caused infirm biofilms fall off when gas and water mixed with each other. This phenomenon was more obvious inside the plastic filling reactor. Once the infirm biofilms came off, turbidity and color of influent water would increase, while the influent water quality also changed a lot.

\subsection{Comparison and analysis of nitro- gen removal efficiency}

The efficiency of the biofilm reactor for removing nitrogen that existed in water in different form was shown in Fig 3 (a), (b), (c) and (d) as follows. Fig 3 (1) shows the TN removal efficiency of two reactors. The influent TN concentration was $7.20-8.51 \mathrm{mg} \cdot \mathrm{L}^{-1}$; the final effluent concentration of TN was $6.36-7.78 \mathrm{mg} \cdot \mathrm{L}^{-1}$ and $2.58-3.11 \mathrm{mg} \cdot \mathrm{L}^{-1}$ respectively inside the PFR and FBR. Thus, it was clear that FBR was more effective for removing $\mathrm{TN}$ at an average removal rate of $62.18 \%$, which was in line with the analysis of nitrogen removal efficiency. The TN removal rate of PFR was far lower and only 


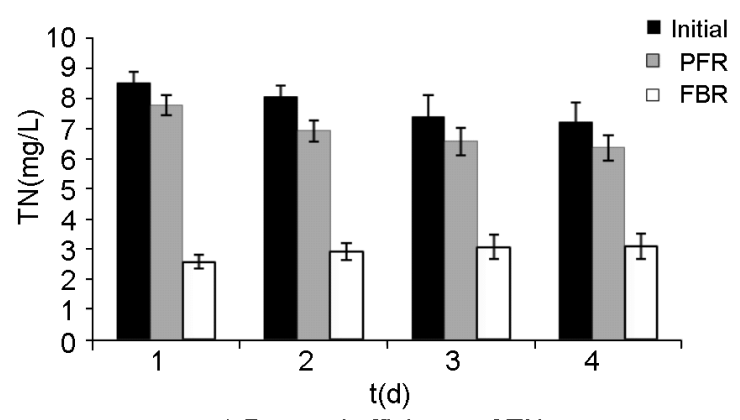

a) Removal efficiency of TN

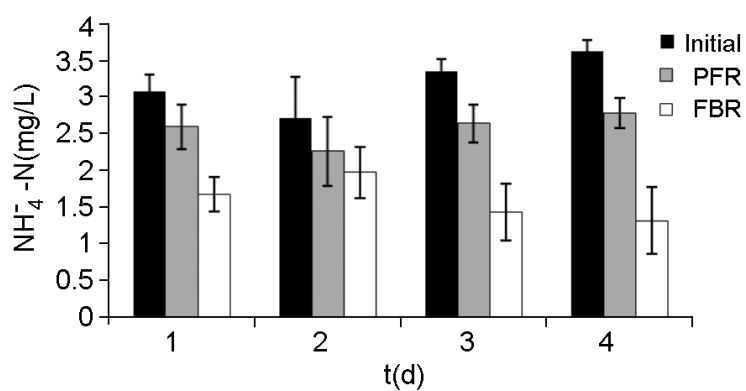

b) Removal efficiency of $\mathrm{NH}_{4}^{-}-\mathrm{N}$

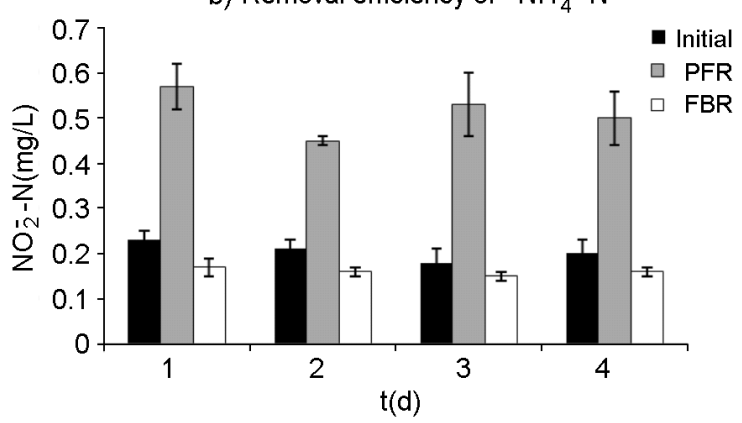

c) Removal efficiency of $\mathrm{NO}_{2}^{-}-\mathrm{N}$

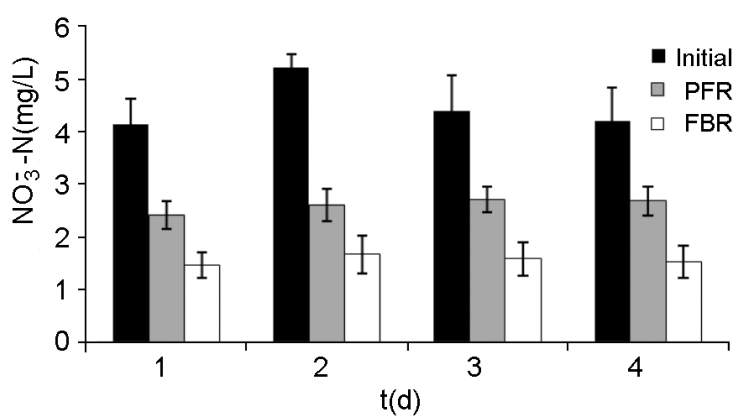

d) Removal efficiency of $\mathrm{NO}_{3}^{-}-\mathrm{N}$

Fig. 3. Removal efficiency of nitrogenous compounds

$11.40 \%$. During its operations, FBR could remove nitrogen at a higher rate, as it could create a microenvironment for nitration and denitration.

By observing Fig 3 (b), it was discovered that the influent $\mathrm{NH}_{4}^{+}-\mathrm{N}$ concentration was $2.71-3.62 \mathrm{mg} \cdot \mathrm{L}^{-1}$, FBR kept a relatively high removal rate within the remediation period, the removal rate declined a little on the sec- ond day possibly because the biofilms were not quite stable on the bamboo filaments under the water erosion, but the removal rate was high on the third and fourth day, which indicated that the biofilms had become adaptable to the sewage. As a whole, the $\mathrm{NH}_{4}{ }^{+}-\mathrm{N}$ removal rate of $\mathrm{FBR}(48.55 \%)$ was much higher than that of PFR (19.22\%) within the experimental period. Nitrite and nitrate bacteria, which could easily adhere to bamboo filaments, were observed mainly owing to the conversion of $\mathrm{NH}_{4}{ }^{+}-\mathrm{N}[12]$.

As shown in Fig 3 (c), it was found that the influent $\mathrm{NO}_{2}^{-}-\mathrm{N}$ concentration was $0.18-0.23 \mathrm{mg} \mathrm{\textrm {L } ^ { - 1 }}$, while the final effluent $\mathrm{NO}_{2}{ }^{-}-\mathrm{N}$ concentration was $0.45-0.57 \mathrm{mg} \cdot \mathrm{L}^{-1}$ and $0.15-0.17 \mathrm{mg} \cdot \mathrm{L}^{-1}$ respectively. The $\mathrm{NO}_{2}^{-}$ $\mathrm{N}$ removal rate was $21.64 \%$ inside the FBR, but declined by $151 \%$ inside the PFR. Thus, it was clear that the $\mathrm{NO}_{2}^{-}-\mathrm{N}$ removal rate wasn't high in both reactors and $\mathrm{NO}^{-}-\mathrm{N}$ was even accumulated inside the PFR. The higher $\mathrm{NH}_{4}^{+}-\mathrm{N}$ and $\mathrm{NO}_{3}{ }^{-}-\mathrm{N}$ removal rate suggested that they were heavily converted into $\mathrm{NO}_{2}^{-}-\mathrm{N}$ when the reactors were under operations, as a result of which the $\mathrm{NO}_{2}{ }^{-}-\mathrm{N}$ removal rate was always low [13].

By observing Fig 3 (d), it was discovered that the influent $\mathrm{NO}_{3}{ }^{-}-\mathrm{N}$ concentration was $4.13-5.22 \mathrm{mg} \mathrm{L}^{-1}$, while the final effluent concentration of $\mathrm{NO}_{3}^{-}-\mathrm{N}$ was $2.42-2.71 \mathrm{mg} \cdot \mathrm{L}^{-1}$ and $1.46-1.67 \mathrm{mg} \cdot \mathrm{L}^{-1}$ respectively inside the PFR and FBR. The $\mathrm{NO}_{3}^{-}-\mathrm{N}$ removal rate of FBR (65.29\%) was higher than that of PFR $(41.87 \%)$. As the reactions carried on, the $\mathrm{NO}_{3}{ }^{-}-\mathrm{N}$ removal rate kept relatively high inside both reactor. With the carbon source of endogenous carbon, denitrifying bacteria removed nitrogen by denitration. When the FBR was under operations, numerous groove-shaped structures on the bamboo filaments facilitated the appositional growth of denitrifying bacteria and led to a sustained increase of $\mathrm{NO}_{3}^{-}-\mathrm{N}$ removal rate, which was higher than that of the PFR.

Based on the removal efficiency for nitrogen pollutants, it may be inferred that an aerobic zone easily formed on fillers due to full aeration of the reactors when PFR and FBR were operated, thus facilitating the appositional growth of some aerobic microbial films. Compared with plastic fillers, there were many deeper groove-shaped structures on bamboo filaments that microorganisms were fixed on the filaments and deep inside the grooves, where the depth of the aerobic zone was dependent upon oxygen delivery rate and loss rate [14]. The mixing efficiency of gas and water was much higher on the fillers than that deep into the grooves of the fillers, where the concentration of dissolved oxygen was lower than that on the 
fillers. An aerobic zone and an anaerobic zone formed on the fillers and deep into the groove. All these phenomena would be much more evident as the treatment carried on. Thus, nitration and denitration would be synchronous when FBR was under operations, in order to reduce the accumulation of $\mathrm{NO}_{2}^{-}-\mathrm{N}$ inside the reactor. During water treatment, the bamboo filaments were decomposed into water soluble organic substances. As solid carbon sources, they continuously and effectively provided carbon for microorganism, and cellulose was rich in trace elements, which could accommodate needs of denitrifying bacteria for these elements, increase denitration rate and guarantee continuous efficient nitration and denitration of microorganisms[15]. When FBR was under operations, the turbidity and color of water discharged from the blow-down pipe were much lower than those inside PFR. Besides, less sludge was produced inside FBR. The microscope detected lots of nematodes inside the FBR. The turbidity and color of effluent water declined, perhaps because nematodes swallowed a great deal of inorganic and organic particles inside the reactor. Since bamboo filaments are highly hydrophilic, it is easily to form a more complicated and longer food chain, in which advanced microorganisms can better prey on inferior ones. As a consequence, less sludge is produced.

\subsection{Comparison and analysis of TP re- moval efficiency}

Both FBR and PFR were somewhat effective for removing TP. When the influent TP concentration was $0.15-0.25 \mathrm{mg} \cdot \mathrm{L}^{-1}$, the final effluent TP concentration was $0.10-0.18 \mathrm{mg} \cdot \mathrm{L}^{-1}$ and $0.12-0.20 \mathrm{mg} \cdot \mathrm{L}^{-1} \mathrm{re}-$ spectively inside the FBR and PFR. FBR removed TP more effetively than PFR, whereas the TP removal rate was much lower than the $\mathrm{TN}$ removal rate on average. On one hand, according to principles of biological phosphorus removal, only a little phosphorus is available for biological assimilation, but mostly stored inside polyphosphate accumulating bacteria and removed through sludge discharge. In this experiment, very little sludge was discharged owing to extremely small yield of sludge. On the other hand, some carbon sources are consumed with the formation of nitrate nitrogen inside the systems. As a result, there is a lack of glycogens (namely carbon sources) inside the polyphosphate accumulating bacteria. However, glycogens are just like "engines" of the systems. It will be more impossible to absorb excess phosphor if glycogens are in shortage. In the whole experimental process, aeration and oxygen supply also damaged normal physiological features of polyphosphate accumulating bacteria. Thus, the TP removal rate of the FBR was not quite high compared with pertinent research findings.

\subsection{Comparison and analysis of biomass}

The removal efficiency of FBR was higher than that of PFR, because there were more active indicative microorganisms on the bamboo filaments than those on the plastic fillers as observed by a microbioscope.

The microbioscope detected that both bamboo filaments and plastic fillers were full of microorganisms, whereas there were more abundant biotas and a greater amount of more active indicative protozoan vorticellidae, paramecium, epistylis and flagellate. The zoogloeas were huge and highly transparent. Under the same conditions, there were only a small amount of vorticellidae and colpoda reniformis but more flagellate on plastic fillers. The zoogloeas appeared to be messier and less transparent.

When the bamboo filaments were used, some loose bamboo fiber formed and temporarily functioned as skeleton of the zoogloeas, in order that exotic microorganisms rapidly accumulated on the bamboo fiber to constitute simple zoogloeas. In this way, the formation of filamentous bacteria was unnecessary on the simple zoogloeas. The fallen bamboo fiber was distributed so intricately that net-shaped biofilms formed with the adhesive forces of indigenous microorganisms, colloid in water and extracellular polymeric substances. Hence, this was the main reason why lots of microorganisms existed on the bamboo filaments and the reason why the bamboo filaments were better than the plastic fillers. Furthermore, water soluble organic substances were steadily released from the bamboo filaments, thus providing nutrient elements necessary for growth and proliferation of microorganisms [16].

\section{Conclusions and discussions}

Under the same experimental conditions, it was feasible to remedy polluted waters by utilizing bamboo filaments and plastic fillers as biofilm carriers. When bamboo filaments were used, the $\mathrm{COD}_{\mathrm{Mn}}, \mathrm{TN}, \mathrm{NH}_{4+}-\mathrm{N}$ and $\mathrm{NO}_{3-}-\mathrm{N}$ removal rates were $65.70 \%, 62.18 \%, 48.55 \%$ and $65.29 \%$ respectively. They were $9.29 \%, 11.40 \%$, $19.22 \%$ and $41.87 \%$ respectively when plastic fillers were employed. The $\mathrm{NO}_{2}-\mathrm{N}$ was mostly accumulated inside the PFR, so the TN removal rate was lower. However, when the influent TP concentration was $0.15-0.25 \mathrm{mg} \cdot \mathrm{L}^{-1}$, the final effluent TP concentration was $0.10-0.18$ $\mathrm{mg} \cdot \mathrm{L}^{-1}$ and $0.12-0.20 \mathrm{mg} \cdot \mathrm{L}^{-1}$ respectively inside the FBR and PFR, thus the TP removal rate was relatively low. 
The inert biological carriers (e.g. plastic fillers) were compared with degradable ones (e.g. bamboo filaments). Many organisms easily formed on the bamboo filaments, because the filaments had plenty of hydrophilic hydroxyls (including hydroxyls, methylene groups and amino groups), special groove-shaped structures and high adhesive performance of organisms, so the FBR showed higher removal efficiency.

Bamboo filaments, as solid-phase carbon sources, steadily released water soluble organic substances and promoted denitration of microorganisms. When they were used, some loose bamboo fiber easily formed to create a netshaped biofilm, which made the filaments more effective for capturing macromolecular organic and inorganic particles like nets.

\section{Acknowledgements}

This study was sponsored by the Science and Technology Plan Projects of Ministry of Housing and Urban-Rural Development of the People's Republic of China (grant no. 2015K6-014 and R22016061) and the Young Project of Xuzhou Institute of Technology (grant no. XKY2016231)

\section{References}

1. M.T. Dokulil, K.Teubner,Eutrophication: Causes, Consequences and Control [M]. Dordrecht: Springer Netherlands, pp.1-16, 2011.

2. L. Zhu, Z.Li, T.Ketola, Ecol. Eng., 37, 1460, 2011.

3. H. Qin, Z. Zhang, M.Liu, H.Liu, Y.Wang, X.Wen, Y.Zhang and S.Yan, Ecol..Eng., 95, 753, 2016.

4. H. Wu, J.Zhang, P.Li, Ecol. Eng., 37, 560, 2011

5. X. Zhou, U. Wang, J .Environ. Sci., 22, 1710, 2010.

6. A. Cristina, M.B. Josep, M.Isabel, J.Salas, J.Garcна, Ecol..Eng., 80, 108, 2015.

7. M. Rodgers, X. Zhan, Rev. Environ.Sci.Biotechn.,2, 213, 2003.

8. W. Zhang, Y. Zhang, L.Yin, Acta Scient. Circumst., 37, 1787, 2017.

9. W. Cao, H. Zhang,Y. Wang and J.Pan, Ecolog. Eng., 42, 146, 2012.

10. CaoW., S.Tan, Chinese J. Environ. Eng., 4,1585, 2010.

11. C. Wang, J.Xi, H.Hu, Acta Sci. Circum Stunt., 27, 53, 2007.

12. L. Wang, B. Xi, L. Zhang, Environ. Pollut. Prev., 34, 29, 2012.

13. L. Xie, B.Cai, D. Yang, J. Tongji Univ. (Natural Science), 37, 224, 2009.

14. S.Yang, F.Yang, Z.Fu, Bioresour. Technol, 100, 2369, 2009.

15. F.Zhao, S.Xia, X.Yang,W.Wang, J.Li, B.Gu, Z.He, Ecol. Eng. 40, 53, 2012.

16. L.Su, J.Chen, W.Cao, Y.Song,, J. Kunming Univ. Science and Technology (Sci, Techn.) 35, 93, 2010. 